\title{
Bis (triphenylphosphine) phenyl nickel (II) chloride
}

\author{
内田安三, 干鯛真信, 柏木俊彦, 池内達郎 \\ (東京大学工学部) \\ $\mathrm{Ni}\left(\mathrm{PPh}_{3}\right)_{4}+\mathrm{PhCl} \longrightarrow \mathrm{PhNi}\left(\mathrm{PPh}_{3}\right)_{2} \mathrm{Cl}+2 \mathrm{PPh}_{3}$ \\ $\begin{array}{lll}1107.8 & 112.6 & 695.8\end{array}$
}

\section{I. 製 法}

以下の操作はすべて窒素中でおこなう。まず小型のシュレンク型フラスコに tetrakis(triphenylphosphine)nickel (0) （注意 1 ） $0.94 \mathrm{~g}(0.85 \mathrm{mmol})$ とトルエン $15 \mathrm{ml}$ を入れ，かきまぜて溶解する（注意 2 )。そこに chlorobenzene $0.5 \mathrm{ml}$ (4.9 mmol) を加え, 室温で 10 20 分かきまぜ反応させる。その後, 反応溶液を一日放置すれば, 黄かっ色の 結晶が析出する。口過し, 結晶は石油エーテルで洗い減圧乾燥する。ロ液に石油エーテル $5 \mathrm{~m} l$ を加え放置すればさら に目的の結晶が析出する。えられる bis(triphenylphosphine)phenyl nickel (II) chloride は $0.42 \mathrm{~g}$ (収率 $70 \%$ ) であ る(注意 3 )。

\section{II. 注意事項}

(1) tetrakis(triphenylphosphine)nickel（0） は以下の方法で合成する。 $500 \mathrm{ml}$ の二つロフラスコにエーテル 200 $\mathrm{m} l$ を入れ, nickel (II) acetylacetonate $5 \mathrm{~g}(0.02 \mathrm{~mol})$, triphenylphosphine $20 \mathrm{~g}(0.08 \mathrm{~mol})$ を加えてかきをぜ溶解 し， $-30^{\circ} \mathrm{C}$ に泠却する。diethylmonoethoxy alluminium $8 \mathrm{ml}$ を加え，しょじょに室温にもどし，かきまぜをやめ放 置する。生成したかっ色の結晶をロ過し，エーテルで洗い減圧乾燥する。

(2) マグネチックスターラーを使用する。

(3) bromobenzene をもちいる場合も同様な操作でえられる (収率 70\%)。

III. 性質

空気中でかなり安定である。ベンゼン，トルエン，クロルベンゼンに可溶。溶液中ではかなり不安定。n一ヘキサン に難溶。

$\mathrm{Ni}\left(\mathrm{PPh}_{3}\right)_{2} \mathrm{PhCl}: \mathrm{mp} 122 \sim 123^{\circ} \mathrm{C}$ (dec. 窒素下)。

$\mathrm{Ni}\left(\mathrm{PPh}_{3}\right)_{2} \mathrm{PhBr}: \mathrm{mp} 124 \sim 125^{\circ} \mathrm{C}$ (dec. 窒素下)。

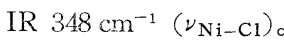

\section{IV. 本法の利点}

從来，アリールニッケル錯体をうる方法としては，J. Chatt ら゙よる nickel (II) halide-phosphine 錯体とグリニ ャール試薬との反忍が知られている。また最近, D.R. Fahey 2) によって ethylenebis(triethylphosphine)nickel (0) と aryl halide の反忘が報告された。これらの方法ではオルト置換基をもつ場合にのみ安定な錯体として単離され，無置 換，メタ，パラ置換の場合には単離することができなかった。本法の tetrakis(triphenylphosphine)nickel (0)に対す る酸化的付加反応によると, 従来の方法によっては単離されなかった無置換, あるいはメタ, パラ置換アリ一ル錯体を 容易にうることができる。この方法によってここに示した二つの生成物の他に，o-, m- , p- $\mathrm{Me}, \mathrm{Cl}, \mathrm{OMe}$ 等の生成物 がえられている3)。最近池田ら ${ }^{4}$ は diethyl (dipyridyl) nickel (II) と chlorobenzene の反応により phenyl(dipyridyl) nickel (II) chloride が生成することを報告している。

\section{引用文献}

1) J. Chatt, B.L. Shaw, J. Chem. Soc. 19601719

2) D.R. Fahey, J. Am. Chem. Soc. 92404 (1970)

3) M. Hidai, T. Kashiwagi, T. Ikeuchi, Y. Uchida, J. Organometal. Chem. 30279 (1971)

4) M. Uchino, A. Yamamoto, S. Ikeda, J. Organometal. Chem. 24 C 63 (1970) 